\title{
The Possible Utopia: A Gift of Hope and Reason for Action-Changing the Course of History!
}

\author{
Patricia Rodiles, José Ángel Chevalier \\ School of Business, Interdisciplinary Center of Postgraduate Research and Consultancy, Universidad Popular \\ Autónoma del Estado de Puebla (UPAEP), Puebla, México \\ Email: rodiles pat 03@yahoo.com.mx
}

Received 29 September 2014; accepted 11 April 2015; published 15 April 2015

Copyright (C) 2015 by authors and Scientific Research Publishing Inc.

This work is licensed under the Creative Commons Attribution International License (CC BY). http://creativecommons.org/licenses/by/4.0/

(c) (7) Open Access

\begin{abstract}
Today, the world's current state reflects how we are living in a critical and chaotic time which brings multiple and challenging problems in social, economic, ecological and cultural aspects among many others. However, for women and men of good will, who yearn for a better, more human, and more solidary world, it is very encouraging that, despite this sad reality, there is a "possible utopia" that would change the course of history. But everybody asks themselves: How can we face a challenge of this magnitude? What path should we follow? Will man be able to change his mind and heart to do so? Will man have the faith, spirit and strength required? Will humanity be able to transform its creations of death into structures of life? What story should be built from now on to the future? It is an enormous and extremely complex task to have a better world, but if we are not willing to start, here and now, where and when will it be? And if we do not, who will? In this sense, Einstein and Edmund Burke challenge us as humanity, with their great motivating and appropriate statements: "If you want different results, do not do always the same" (as cited in Davidovich, Nikolay, Laugerman, \& Commodore, 2010: p. 23) and "For evil to triumph [on earth] it is enough that good men do nothing" (as cited in Bartlett, 1968: p. 454; Kirk, 2009: p. 204; Landau, 2006: p. 222). Now, more than ever, it is the best time to start. Without a doubt, it is a monumental challenge, but also a "unique opportunity" that demands the availability of men and women, bold and brave, in order to unite their wills, to make possible the impossible, because our future as humanity is truly at stake.
\end{abstract}

\section{Keywords}

Possible Utopia, Virtuoso Leap for Common Good, Shared Responsibility for Integral Human Development, From Dictatorship of Relativism towards Conversion, Faith, Reason, Values and 


\section{Ethics for Building Virtuosity}

\section{Introduction}

The purpose of this article is to call men and women to the most necessary consciousness in order to assume their faith, reason, and will, and decide if they want to be players or spectators of history? All of mankind will be, after all, affected by decisions, actions, and negative consequences of their own actions such as poverty, hunger and misery of millions of human beings, degradation and progressive destruction of the planet and the biosphere, to man apathy, the proliferation of violence, insecurity, conflicts, riots and wars, as well as the multiplication of crisis: of values, spiritual, economic, anthropological, financial, food, familiar, etcetera.

Historically, the incredible scientific and technologic progress we have reached is paradoxical, without having achieved the spiritual, ethical, moral and religious issues. Nowadays, this is reflected in the gap between physical and spiritual being, which forms the integral nature of the human person. It explains the inconsistency between these great achievements, unimaginable to our Paleolithic ancestors and our illiteracy in faith and ethical and moral values that build the virtuosity in families, societies, and cultures.

It is enough to mention a key fact congruent to Max-Neef's1 (1986) thinking about the historical magnitude of time. This way of thinking considers that the planet was born more than a billion years ago and that the existence of all humankind started in the last thousandth of that time (1 million years). It is appalling to think that in just ten thousandths of that period (100,000 years), human activity has led to this mess and world chaos that we are living at the dawn of this new century, in our postmodern era. This abstraction should make us think about the perfect order governing the universe against the serious disorder that man has been institutionalized by on the planet, as Max Neef says, for destroying not only the system, but also himself.

It requires making a stop along the way and introspectively asking ourselves: Where are we going? What would have to happen for human beings to decide goodness, in their thought and action, not only for himself, but for others, for the common wellbeing, for society's sake, for the world's sake? Has the teaching of multiple historical mistakes and successes committed not been enough? What kind of society do we want to achieve? What is needed so that human efforts are really a proactive and operational runway to the true integral human development? What values should be a framework, bound, in the design of educational, social, economic, environmental policies, etcetera? Is it a really impossible utopia, or is the "possible utopia" for getting the best world and a version of ourselves?

\section{The Operation of the "Possible Utopia" in Order to Change the Course of History}

Every human being life's story is different for many reasons-nationality, culturally, educationally, religiously, etcetera. Besides time as a factor, the experiences we live transform us. As this happens, experience and maturity are acquired. However, at the end of every single life, which cannot be changed, for better or worse, is the inheritance bequeathed to one's family and to the future generations. For this reason, it is very important to reflect when there is still time one's what we are doing, what we did or failed to do, in all states and areas of our lives: personal, family, social, professional, labor, institutional, etcetera.

Looking back to the infancy years allows us to realize the quality of our education and training, family, formal, and especially moral, as a pillar of future development. In youth, it is a very profitable exercise, with enthusiasm that can lead to improving the world; but also in adulthood, it is very fruitful, because you still have time to rectify many unfortunate episodes. Hence the vital importance of proper sense of each person's life because it influences their decisions and actions, which at the same time will impact positively or negatively on all, from the family environment to the social and institutional environment, with its many current issues such as poverty, hunger, inequality, unemployment, violence and insecurity, human trafficking, organized crime, cor-

\footnotetext{
1“If we imagine a two feet long line as a representation of time from planet birth to the present time, the whole existence of mankind would be included only in the last millimeter. Within this perspective is impossible to deny the effectiveness of human beings to alter, quickly and dramatically, a program dating back over a billion years. It is even more surprising when one realizes that the most intensive efforts to drag us into a total crisis, have only occurred in one ten-thousandth of a millimeter in this imaginary line (...) Add to this that human beings were last among the top creatures to emerge on the face of the earth, it is certainly unsettling wonder why such an old system has given rise to a new component (might say odd) having such an amazing ability to destroy the system and to destroy himself. It is beyond my power to discover an answer to this riddle and I only raise this because often strikes my fancy” (p. 43).
} 
ruption, immigration and so on.

In this context of serious and recurrent crises, the following reflection is explanatory about the values and ethics deficit that we experience at the beginning of this century.

One might ask, with so many practical important problems for the population does it make sense to speak about values and ethics? Is that item not one deferrable, not urgent? We think the question should be reversed. How can economic policies be designed, allocated resources, determine priorities without discussing the ethical, the morality of what is being done at the light of the values that should be the objective of development and democracy? [In the whole world] (...) this discussion has been postponed. It's time to take it up because it can shed much light on an era of strong confusions (Kliksberg, 2002).

This scenario could depress many people, but the story also uncovers many events, people and exemplary organizations that changed at different times, spaces and areas, as well as many difficult and controversial situations. An excellent example is Dr. Muhammad Yunus, known as the "Poor's Banker" and 2006 Nobel Peace Prize. He is a man committed to the common well-being, with history and its learned lessons and above all, consistent with his thinking and doing. In 1974, he was faced with the terrible famine in Bangladesh and he sympathized with his compatriots in distress and as a visionary economist conceived a brilliant idea to help them, the microfinance, by founding the Grameen Bank with an unorthodox bank philosophy. The following comment from Dr. Yunus (1998) outlines his vision of poverty and hunger and human suffering. In his own words, and mine too, are morally unjustifiable:

Brilliant economic theorists do not consider it useful to devote their time to studying the problems of poverty and hunger. They want us to believe that these problems will solve themselves, when the prosperity's wave flows over the nations. These economists who focus their talent on the analysis of the processes of development and prosperity, do not even give a distracted look to poverty and hunger, issues they judge secondary. I am convinced that if the world is fighting against poverty, among its priorities, we can build a universe that we will feel legitimately proud and we will not feel shame as it is today. (p. 79)

The possibility for the required 180 degrees turn that we must do, as a conscious process, creating a story for the protagonist of humanity, has a key question, wording of the following reflection: "[The deep current crises may] thus become an opportunity for a virtuous leap of each of us, accompanied by a greater passion for the common and realistic construction of the good life and good governance” (Scola, 2009). The question is: are we willing to take the virtuous leap that releases us from the vicious circle that we have led? The only true and valid response, involves taking the following requirements:

1) The "relativism dictatorship's” liberation, as Cardinal Joseph Ratzinger (2005) named it. Because by kidnapping ethics and values, it limits and obstructs the co-responsibility and commitment.

2) The "real learning from our historical mistakes" for the arising of the conscience, faith, reason and will, and above all the heart's conversion, — which makes shared responsibility functional, as a powerful and complete antidote against indifference and selfishness.

The first aspect, the "relativism dictatorship" impoverishes us as individuals and as humanity, because “...to educate we must know who the human person is in order to know its nature. The increasing prominence of a relativistic understanding of nature presents serious problems for education, especially for moral education, jeopardizing its universal extension. Yielding to this kind of relativism makes everyone poorer” (Benedict XVI, 2009: para. 61). Therefore, the vital importance of each and every man is to make them aware of this Machiavellian trap and crave to be free from its influence. We are also warned about the spread of relativism in the world with all its severe consequences:

We indeed see spread, (...) a things vision according to which all the divine absolute is replaced by the human absolute, establishing oneself as a source of morality for himself. (...) God no longer exists as the creator of man and as author of the moral law, but it is man's final criterion of good and evil. This relativist and subjectivist moral matrix is projected onto a heartbreaking utilitarianism in which it is good and just not what we know as such, but what is merely useful, thus giving rise to recurrent abuse of the weakest and, notoriously, to unbridled hedonism that confuses the good with the simple life's enjoyment. (...) Keep in mind a certain criteria to the serious issues of truth and the real possibility for man to know the light of reason and faith, is a matter that today substantially compromise the destiny of man, culture and society. 


\section{(Sodano, 2009)}

This immanentist vision was also warned by Einstein, who recognized widely the existence and God's greatness: "In view of such harmony in the cosmos which I, with my limited human mind, am able to recognize [it is almost incredible that] there are still people who say there is no God, but what really makes me angry is they quote me for support of such views.” (As cited in Calaprice, 2011: p. 336; Clark, 1973: p. 400, Jammer, 2002: p. 97)

We can see this danger, precisely for the logic that is intended to address many of the problems we experience every day, because there are double speeches appealing to these principles, but in practice doing exactly the opposite. There are many examples of this approach and unfortunately we verify for the sad world stage that we have created.

The men's relativistic, subjective and permissive logic which pretends the God's outshine from the world, confirms the GK Chesterton's assertion: "When someone stops believing in God, immediately believes anything.” (As cited in Ahlquist, 2006: p. 265; Cammaerts, 1937; Knowles, 2009: p. 211; Novak, 2009: p. 34; Shapiro, 2006: p. 149, n. 25; Strobel, 2005: p. 51; The American Chesterton Society [ACS]; Van Inwagen, 1994: p. 57).

The key question is, what is the direct consequence of this immanentist vision? Unfortunately the response is that human being automatically lose the life's sense. In this way, man first is deceiving himself, immediately is auto naming oneself as the "owner of good and evil”, and finally he creates gods according to his limited personal measurement: money, power, fame, etcetera. Unfortunately through a life's relativistic vision, man denies for himself — automatically — the joy of knowing, learning and living in the fullness of truth "with the two wings that man has for know it: the faith and reason” (John Paul II, 1998).

The other aspect, the "real learning of our historical mistakes" in the humanity's common experiences framework, means that we all feel responsible for everyone, with our common problems that if we face jointly, they can be resolved in a more efficient and effective way. Unfortunately, throughout history there have been many famous people who never were committed convincingly, yielding to their personal interests, dishonored their really human being, and pledged their future not only temporal but also eternal. It is a pity because from there, they can not fix the errors and mistakes they made here!

Einstein (1967) also appealed to the recognition of religious values as a guide for our lives when he said "the highest principles of our aspirations and judgments are given to us by the Judeo-Christian religious tradition. It is a very high goal which, with our weak capabilities, we can only achieve inappropriately, but it gives a secure foundation to our aspirations and assessments.” (p. 27).

However, this is the great privilege of free will. For this reason the most important issue is the minds and heart's continuous calling to conversion and, the reason united, complemented and enriched with faith, to make them present in our everyday thoughts and actions. In this challenging time faith is the most necessary, because if man continues with his pretension to replace God, author of the moral law and virtuosity, for the man himself as a morality's source, with all relativism, hedonism, consumerism and materialism implied, then there would not be future.

At this crucial moment in history we should ask ourselves why so many important political leaders, governors and state's heads are asking and have been granted audiences with Pope Francis, who represents precisely the so necessary moral authority in our world? After the political, economic, social, etcetera globally disenchantment, will these leaders become aware of that the world's construction is deficient in the values that should guide it? And if it continues on this way where do civilization and culture will go?

The challenge we face in the short, medium and long term, is precisely the achievement of shared responsibility and unwavering commitment by, as we mentioned, the release of the "dictatorship of relativism" and a "real learning of our historic mistakes”. Thus we will undertake on the virtuoso leap to life's culture and love's civilization for the true integral human development and therefore sustainable!

\section{Conclusion}

The history's objective knowledge and memory of the past, awareness us about human nature, which is capable of the greatest acts for the common well, but also of the most terrible ones, that cause destruction, death, suffering and pain. Due to the destructive acts, many people get depressed, frightened and they halt, but without any solid foundation, because even in the Bible (Matthew 13: 24-30, 36-43, New American Bible) it is mentioned 
that "they will grow together the wheat and the weeds until the harvest is to take place". The important question to avoid the temptation of pessimism and fatalism will be: Have we thought, on some occasion, what our world would be if all stages of the story had we lived only among shadows, without a glimpse of a single trait of kindness, to share, to humanize, to help, to cooperate, to improve?

For this reason, it is essential to raise awareness that at some point in our lives we will have to respond with the entirety of our human being, physical and spiritual, the following question: what did we do with our knowledge, experience, faith and will, against our world civilization's sad scenario, diagnosing diseases we suffer: selfishness, insensitivity, apathy, indifference, complacency on our own comfort zones and already resolved lives?

May our response reflect a human being who has remounted his selfishness and immanence, because he reasons and lives in the interest of the common well and transcendence. It would confirm that he has understood, assumed and lived the following thoughts: "Man finds God behind every door that science can open" (Einstein as cited in Brian, D. \& Brian, K., 2005: p. 167); "the more I study science, the more I Believe in God” (Einstein as cited in Holt, 1997; Strobel, 2005: p. 57); “Is a sincere faith the faith that never acts?” (Racine, 1692: p. 5; Racine, 1895: p. 13, 105; Racine, 1982: p. 162; see also Hourani, 2012: p. 263); and finally “As a body without the spirit is dead, a faith without actions is also dead” (James 2: 26, New American Bible). Summarizing, he would be a human being who has gotten his mind and heart's conversion!

The "possible utopia" proposed in this paper, is the big challenge for all men and women of good will and for all those privileged that have had access to a college education and especially to a postgraduate level. So let us ask ourselves is it really helpful all the knowledge, experience and apprenticeship, if it does not resolve our problems, if it does not transform our painful realities and does not improve our world? Our responsibility and commitment is greater, because it is not valid to believe that this privilege is only for their own benefit.

Our research has the full sense of building and improving all these aspects of our societies. We believe that should be the main task of all of us, great human family, in our passage through this most beautiful planet earth. In our hands there is a serious responsibility to have an impact on our current history, as part of our sacred freedom, with our good and bad decisions. Do we settle for being spectators of what others do, while "my" immediate environment is not so bad? If so, we have no right to complain. Or do we dare to be courageous protagonists of the story of our day to day, to change not just "my” immediate environment but also the farthest?

There will be many people who consider all this utopic. However, there will be many people who can visualize it possible, as it was for Nelson Mandela, a man deeply committed, who said: "everything seems impossible until it's done.” (As cited in Biwi, 2013: p. 24; Egeberg, 2012: p. 180; Petras, K. \& Petras, R. 2014: p. 166; Nelson Mandela facts weebly.com; Neumann, 2012, p. 27; Ridley, 2015; Williams, \& Denney, 2015: ch. 2).

Mandela really proved it with his own life's witness and legacy. Will not it be also the time for action for all of us, to take over about immanence and relativism, and to pray for all humankind's conversion? It is supposed that we know more, we have awakened and raised awareness and really we want to change the history's course. Isn't it?

Now it is the best time to let us transform in change dynamic agents, in order to take the virtuoso leap, -according my thesis of masters - to "create an inclusive culture in which those who have more, become sensitized to those without, so that this way, they will be motivated to support all proposals for concrete actions and practical help fraternal solidarity with the needy ones. Until we do this, we can consider ourselves as truly human beings, able to create a true culture of fraternal commitment, based on the highest values and principles of man: social justice, human dignity, sensitivity to the plight of the poor, responsibility, solidarity, freedom, human development and integral development” (Rodiles, 2005).

Being the architects of a new culture is certainly possible! The potential of every human being, once awake, aware and proactive, to make these changes is enormous, and if there is more good will of those who want to be determined agents of change, can really lay the foundation for building a better world, more humane conditions, with opportunities for all and equitable! All concepts, we now see so overshadowed by their antonyms can be perceived everywhere.

But let's better focus on the "possible utopia” we have ahead challenging us as humanity, to the philosopher Charles Taylor warning's wording when he said: "our time is characterized in that the discussion has focused on the media, such as economy and technology, and being very important, it can not be forgotten that they are [only] means at service of ultimate ends” (Taylor, 1995). And these ultimate ends, fall precisely on: the implementation 
and operation of ethics and morality, virtue and values, humanism and the common well, the will and solidarity, shared responsibility and unwavering commitment, learning from mistakes and successes, and the liberation from the dictatorship of relativism towards heart-and-mind conversion. All these ultimate ends give certain and emphatic answers to questions asked, because all of them are also enlightened by faith and supplemented by reason.

Please, let us apply the last ends, which are leading to the "possible utopia” a gift of hope and reason for action. We all together must undertake the virtuous leap in order to change the course of history!

\section{References}

Ahlquist, D. (2006). Common Sense 101: Lessons from G.K. Chesterton. San Francisco, CA: Ignatius Press.

Bartlett, J. (1968). Bartlett's Familiar Quotations: A Collection of Passages, Phrases and Proverbs Traced to Their Sources in Ancient and Modern Literature (14th ed.). Boston: Little Brown and Company. First published in 1855.

Benedict XVI (2009). Encyclical Letter Caritas in Veritate. http://w2.vatican.va/content/benedict-xvi/en/encyclicals/documents/hf_ben-xvi_enc_20090629_caritas-in-veritate.html

Biwi, M. (2013). Nelson Mandela’s Quotes and Tributes. Melville, NY: AA Global Sourcuibg Ltd.

Brian, D, \& Brian, K. (2005). The Unexpected Einstein: The Real Man behind the Icon. Hoboken, NJ: John Wiley \& Sons.

Calaprice, A. (Ed.). (2011). The Ultimate Quotable Einstein. Foreword by Freeman Dyson. New Jersey, USA, Oxfordshire, UK: Princeton University Press.

Cammaerts, E. (1937). The Laughing Prophet: The Seven Virtues and G. K. Chesterton. Victoria, Londres. Methuen \& Co.

Clark, R. W. (1973). Einstein: The Life and Times. Londres: Hodder and Stoughton Ltd.

Davidovich, R., Nikolay, P., Laugerman, B., \& Commodore, C. (2010). Beyond School Improvement: The Journey to Innovative Leadership. Thousand Oaks, CA: Corwin Press.

Egeberg, S. E. (2012). The Art of Life: Make the Changes You Desire. Bloomington, IN: AuthorHouse.

Einstein, A. (1967). Out of My Later Years. Totowa, NJ: Littlefield, Adams and Co.

Holt, J. (1997). Science Resurrects God. The Wall Street Journal, December 24. Dow Jones \& Co., Inc.

Hourani, F. (2012). Daily Bread for Your Mind and Soul: A Handbook of Transcultural Proverb and Sayings. Xlibris Corp.

Jammer, M. (2002). Einstein and Religion: Physics and Theology. Princeton, NJ: Princeton University Press.

John Paul II. (1998). Encyclical Letter Fides et Ratio.

http://www.vatican.va/holy_father/john_paul_ii/encyclicals/documents/hf_jp-ii_enc_14091998_fides-et-ratio_en.html

Kirk, R. (2009). Edmund Burke a Genius Reconsidered (1st. ed., 1967). Wilmington, DE: ISI Books.

Kliksberg, B. (2002). Ética y Economía. La Relación Marginada. Cayapa. Revista Venezolana de Economía Social, 2. Recuperado de http://redalyc.org/articulo.oa?id=62220302

http://www.redalyc.org/pdf/622/62220302.pdf

Knowles, E. M. (Ed.). (2009). The Oxford Dictionary of Quotations. The first edition was published in 1941. New York, NY: Oxford University Press.

Landau, R. S. (2006). The Nazi Holocausto: Its History and Meaning. Salem Road, London, New York: IB Tauris \& CO. Ltd.

Mandela, N. (n.d.). Nelson-Mandela-Facts-Weebly.com http://nelson-mandela-facts.weebly.com/about-nelson-mandela.html

Max-Neef, M. (1986). Economía Descalza. Señales desde el Mundo Invisible. Traducción de Estela Lorca. Prólogo de Leopold Kohr. Coedición de CEP AUR-Centro de Alternativas de Desarrollo y NORDAN-Comunidad. Estocolmo, Buenos Aires, Montevideo: Editorial Nordan. (Trabajo original publicado en 1982 con el titulo From the Outside Looking In: Experiences in Barefoot Economics. Dag Hammarskjöld Foundation. Edición en sueco (1984), Fran andar sidan Förlaget Nordan-Comunidad, (CManfred Max-Neef).

Neumann, A. (2012). Uplifting Quotes on Gratitude and Goodness to Show Appreciation. Cleveland/Akron, Ohio: Good Plus Tech LLC.

Novak, M. (2009). Catholic Social Teaching, Markets, and the Poor. In S. Rundle (Ed.), Economic Justice in a Flat World: Christian Perspectives on Globalization (pp. 21-49). Colorado Springs, CO: Paternoster.

Petras, K., \& Petras, R. (2014). It Always Seems Impossible until It's Done: Motivation for Dreamers \& Doers. New York: Workman.

Racine, J. B. (1692). Athalie, tragedia tirée de l'Écriture Sainte. Paris: D. Thierry. Digitized: March 27th. 2013.

https://books.google.com.mx/books?id=SSrD6_KR3KsC\&dq=Athalie,+tragédie\%3B+tirée+de+l\%27Écriture+Sainte+Rac 
ine\&hl=es\&source=gbs_navlinks_s

Racine, J. B. (1982). Four Greek Plays: Andromache-Iphigenia, Phaedra-Athaliah. Translated with introduction and notes by R.C. Knight, emeritus professor of French, University College of Swansea. Cambridge, London, New York, New Rochelle, Melbourne, Sydney: Cambridge University Press.

Racine, J. B. (1895). Racine's Athalie. Edited with an Introduction, Containing a Treatise on Versification and with notes by Charles Augustus Eggert, Ph.D, professor of Modern Languages, University of South Dakota. Boston, DC: Heath \& CO. https://books.google.es/books?ei=t3ITVcX6KYW4ogSjtoCwBA\&hl=es\&id=bZYXAAAAIAAJ\&dq

Ratzinger, J. (2005). Mass Pro Eligendo Romano Pontifice. Dean Homily of Cardinals College. Apr18. Vatican Basilica. http://www.vatican.va/gpII/documents/homily-pro-eligendo-pontifice_20050418_en.html

Ridley, F. (2015). Nelson Mandela: It Always Seems Impossible until It's Done. Grayslake, IL: ReadZone Books.

Rodiles, P. (2005) El Reto del Milenio: El Combate a la Pobreza ante la Globalización con Sentido Humanista—Propuesta de Solución que Involucra a: Organismos Internacionales, Gobiernos Mundiales, Empresarios del Mundo y Sociedad Civil Internacional. Tesis de Maestría, University of the Americas, Puebla, México.

Scola, A. (2009). La crisis económico financiera puede convertirse en ocasión de un sobresalto virtuoso-Cardenal Angelo Scola. Humanitas, 53. http://www.humanitas.cl/html/biblioteca/articulos/d00065.html

Shapiro, F. R. (Ed.). (2006). Epstein, J. (Foreword). The Yale Book of Quotations. New Haven, CT: Yale University Press.

Sodano, A. (2009). Prólogo al Vademécum de definiciones de las encíclicas antropológicas de Juan Pablo II. http://www.humanitas.cl/html/destacados/Cardenal\%20Sodano.pdf

Strobel, B. (2005). America's Dénouement: The Decline of Morality, Growth of Government and Impact of Modern Liberalism. Baltimore, MD: Publish America.

Taylor, C. (1995). The Ethics of Authenticity. Cambridge, Harvard University Press. Trad. esp. de Pablo Carbajosa. La Ética de la Autenticidad. Introducción de Carlos Thiebaut. Barcelona: Paidós. The Ethics of Authenticity was first published in Canada (1991) under to title The Malaise of Modernity. Concord, Ontario: Anansi.

The American Chesterton Society (ACS). (n.d.). Discover Chesterton. Frequently Asked Questions. When Man Ceases to Worship God. http://www.chesterton.org/ceases-to-worship/

Van Inwagen, P. (1994). Quam Dilecta. In T. V. Morris (Ed.), God and the Philosophers: The Reconciliation of Faith and Reason (pp. 31-60). New York: Oxford University Press.

Williams, P., \& Denney, J. (2015). 21 Great Leaders: Learn Their Lessons, Improve Your Influence. Uhrichsville, OH: Shiloh Run.

Yunus, M. (1998). Hacia un Mundo sin Pobreza. Traducción de Pablo Azócar (9a. edición, p. 79). Santiago de Chile: Andrés Bello. 